\title{
Does Radical Geography Lack an Approach to Environmental Relations?
}

\author{
Ben Wisner
}

1978. Antipode 10(1), 84-95. ${ }^{1}$

As radical Anglophone geography approached the close of its first decade it began to show signs of introspection. Several authors sketched out and pondered its development (Akatiff, 1974; Anderson, 1977; Peet, 1977, Santos, 1975; Wisner, 1977 a). In particular, Peet $(1977,26)$ focuses our attention on an alleged dichotomous development of the spatial and environmental sides of radical geography:

Within radical geography, the theoretical base is increasingly strong in one of the traditional areas of geographic interests (spatial relations) and conspicuously weak in another area (environmental relations). The Marxist theory of spatial relations is becoming more and more sophisticated, especially in the area of underdevelopment processes. In that area a coherent body of theory, developed outside geography, already existed; in addition, there is a condition of crisis in spatial relations between the center and the periphery of capitalism, marked by a series of successful wars of Third World liberation, which has spurred on theoretical inquiry. But there is also an environmental crisis of monumental proportions, and the materialistic approach of Marxist geography can easily be applied to environment-man relations; yet this area of geography remains largely untouched by radical geographers.

I share Peet's concern; however, I believe the situation is not as stark as his words imply. Certainly as a Marxist geographer setting out to participate in the creation of

\footnotetext{
${ }^{1}$ Reprinted with permission from Ben Wisner and Richard Peet.
} 
socialist environmental relations in Mozambique [...], I would hate to believe that the theoretical base of the environmental side of geography is so impoverished.

In this brief paper, I will argue that some theoretical foundation already exists, but in a more scattered and less systematic form. I will begin with a few comments on the schema of development of radical geography employed by Peet. I will then comment on the meaning of "environmental crisis". Finally, I will try to sketch out some alternative approaches to theory-building for the study of environmental relations, political ecology, or, as I would prefer to term the side of Marxist geography emphasizing environmental relations, a socialist human ecology. ${ }^{2}$

\section{The Development of an Environmental Relations School in Radical Geography}

If I am to parallel Peet's description of the development of the spatial school, I mustn't be tempted into reviewing the history of "radical ecology". The welter of paper and activity loosely labeled the "ecology movement" has produced some ideas concerning the relations between capitalism and pollution (e.g., Enzensberger, 1974; Sherman and Hunt, 1972). The middle class generally, and hence a wide range of professionals including biologists, economists, and even some geographers, have been caught up in the collective outrage at what a group of German radicals call "Profitschmutz" [profit-pollution]. However, "radical ecology" as a literature does not stand in the same relation to a Marxist science of environment as "radical urban sociology" [...] to Marxist spatial science. There are three reasons: first, "radical ecology" has produced no coherent theory of environmental relations to inspire geographers in the first place. Some useful superficial historical (Ridgeway, 1971) and global (Weinberg, 1971) overviews have been produced with a broadly "left" perspective, but they can neither be termed Marxist nor theoretical. ${ }^{3}$ Second, in following Peet's method, one must focus more narrowly on what radicals with such classic geographical interests as "resource use", "rural land use", and "environmental perception" have been doing and thinking over the last ten years. These people are by no means identical with the "ecology movement", which brings me to the third reason. In my own experience, a large number of the contributors to a radical analysis of environmental relations within geography have not been closely associated with the "ecology movement" in the first place. This is clearly true of the British and French workers whose writing and practice will be cited later. But it is also true of a

2 Schmidt-Renner (1972, 1973a, 1973b, 1974) has been developing the concept of "Sozialistische Ökologie des Menschen" in a highly industrialized context. I borrow the term from him, but as will be seen below, the practice of revolutionary land use, public health, etc. in the wake of Third World revolutions gives the term a somewhat different content.

${ }^{3}$ The historian Malcolm Caldwell (1978) [...] published a work that links imperialism with energy consumption patterns and mode of production in a way that begins to fill this gap. 
significant number of American geographers, who saw - as I did - early "ecology movement" activities, such as earth Day, as a diversion of energy from the antiimperialist struggle then, focusing on Vietnam and who left North America - as I did in the early 1970s to develop a practice in the Third World or in Europe. If I concentrate on the work of these last-mentioned it is because of my limited acquaintance with the more recently developed foci of radical geography in North America, especially Canada. Also, these remarks do not hold for Danish and some German geographers who experienced a more militant ecology movement with a more developed Marxist content.

Peet recognizes four stages in the development of radical geography. First there were those who tried to find a more socially "relevant" use for techniques and models developed by the new "geographies" of quantification and perception as well as such conventional tools as cartography and "exploration" in general. I know this period well as it was during this time that my closest involvement with Antipode began and ended. Geographer-liberals interested in environmental relations were less numerous than the "spatialists" in common search for relevance but were nonetheless in evidence. For instance, a minority of young geographers involved in "natural hazards" research began to question its focus and relevance in meetings which culminated in an ad hoc session on "social hazards" as the 1972 I.G.U. [International Geographical Union] Man and the Environment Meetings in Calgary.

The second of Peet's stages is critique of the ideology underlying the conventional and new geographic models and techniques. No longer satisfied with seeking "relevant" applications of the existing toolkit, one turns to look at the ways in which these tools are both the product of a particular socio-economic system and tend, by their use, to reproduce that economic socio-system. Here too geographers have not been slow to critique the ideological function of several sets of ideas about the environmental relations that lie at the heart of bourgeois geography as defender of empire. For instance, Buchanon (1973) and Harvey (1974) attack the notion of "overpopulation." O'Keefe (1974), Johnson (1977c), and Wisner (1977b) expose class struggle underlying the definition of a "resource" and the process of underdevelopment of the peasant's forces of production (i.e. they became "resourceless," proletarianized or marginalized by capitalism). Olwig (1976) has similarly attacked the class basis of the ideology of "wildlife conservation," Tachannerl (1976) the idea of "integrated water resource development," and Wisner and Mbithi (1973) the class basis for "transfer of technology for drought-risk reduction." This work of debunking and ideological exposé has much in common with that underway at the same time concerning such ideas basic to "development geography," "development sociology," etc. as "modernization," "growth," and "rationality." Blaut (1977, 1973, 1970) has had a pivotal position since much of his work overlapped both a critique of the "world image" congenial to imperialism and a valorization of the "world image" (including "environmental/resource knowledge") of oppressed classes. This latter influence helped many of us see the relationship between class consciousness and 
"ethnoscience" (e.g. Johnson, 1977a). Paralleling Blaut's attack on the racist ethnographic content of geographic models, Reiser (1973), Baird et al. (1975), and O'Keefe and Wisner (1975) attack the mystifying and controlling function of bourgeois psychological "perception" and "decision" models in geography.

Peet sees the "liberal" and the "critical" stages as having set the stage for the development of a rigorous Marxist analysis of spatial relations. Having demonstrated the existence of a similar liberal and critical practice in the field of environmental relations, I will not surprise the reader by asserting that the stage is set for the parallel development of environmental dialectics - with the key Marxist concept of "mode of production" playing perhaps the same pivotal role in such a theory as has been played by the concept of "rent" in spatial dialectics. However, before I turn to some more detailed notes on the shape of the coming environmental theory, several important issues must be dealt with: why has this environmental theory lagged behind the development of Marxist spatial theory? How far is it safe to push the apparent symmetry between the spatial and environmental sides of radical (at this point I should begin to call it "socialist") geography? Is it not desirable to think in terms of one unified Marxist geography? Indeed is not Marxist geography not simply political economy whose interest is highly focused on certain spatial/environmental aspects of contradictions? Finally, has Peet adequately characterized the "crisis" of "crises" between centre and periphery in the world capitalist system? Is it helpful to differentiate a "crisis in spatial relations" from an "environmental crisis?"

\section{Environmental Dialectics Lack Theory but Not a Theoretical Base}

Peet's third and fourth stages involve first the extraction from classic Marxism of elements necessary for a theory of spatial relations which seem to fit contemporary reality, presumably aiding us not only to understand but also to change that reality. Then one moves on to the stage of making original contributions, additions, to the body of Marxist theory. I lump these stages together as indeed in practice they must be if one is to avoid the most arid scholasticism.

Radical environmental theory is presently in the awkward position of beginning to contribute to evolving Marxist theory (e.g. theory of class consciousness, theory of articulation of modes of production, theory of the relation between forces of production and social relations of production, etc.) without having systematically combed the classics and/or consolidated these findings as has the spatial school over the past few years in the pages of Antipode and Éspaces at Sociétés. Isolated and partial contributions in this direction have been made (e.g. Galois, 1976; Slater, 1977; Datoo, 1977), but for the moment Peet is clearly correct in pointing out a “conspicuous" weakness.

But why this very serious gap? Are those of us interested in the environmental aspects lazy, faint hearted, more eclectic than the spatialists, less rigorous, infantile 
running ultra left-wing dogs of the neo-crypto establishment? The answer is probably simple, even monosyllabic: work. That is, for many of us our practice - especially in the Third World - has meant a later politicization than that of the spatialists and often a qualitatively different one.

Speaking for myself and perhaps half a dozen others who come immediately to mind, our politicization was late - post-civil rights movement. It came in the antiimperialist struggle over Vietnam and Cambodia and later crystallized as Marxism in the day to day practice of field work in such places as Sudan, Kenya, Tanzania, Nigeria, Niger, Senegal, India, Indonesia, Bolivia, and Mexico (again thinking simply of my own practice and that of my closest colleague-comrades). During the mid-1970s when the spatialists were busy reading the Marxist classics, many of us were busy "reading" neo-classical practice: those of us in Tanzania, for instance, tried to study (and to get our reluctant bourgeois students to study) environmental relations in China (e.g. Fanshen, Away with all Pests, etc.), Vietnam (in the pages of Vietnamese Studies), Cuba, North Korea, and the liberated zones of Angola, Guinea-Bissau, and Mozambique. My experience is possibly similar to others' in that my former antiimperialist practice found a new outlet: support work (material medical aid) for FRELIMO $^{4}$. Out of the tension between growing enthusiasm for what I understood to be environmental relations in the liberated zones of northern Mozambique and growing disillusion with environmental relations in neo-colonial Tanzania eventually sprang "Health and Geography of Wholeness" (Wisner, 1976). For many of us working and teaching in geography, public health, planning, resource assessment, development studies such tension was the axis mundi [lynchpin] running through our practice. (Read tension between enthusiasm for China/Cuba, disillusion with India/Mexico in place of my own Mozambique/Tanzania tension.) We learned from our own practice (mostly an experience of failures, e.g. Wisner, 1975a) and from revolutionary practice (e.g. Wisner, 1975b, describing FRELIMO's politicized and politicizing form of "famine relief" at a time when throughout African's Sudan and Sahel savannah countries "famine relief" was synonymous with corruption and inefficiency.) Some of us found time for the "critical" function described above. Some found time for tentative explorations of the classics (Wisner and Mbithi, 1973, end with a sketch of a theory of peasant land use implicit in the writings of Che Guevara and Mao Tse Tung; Johnson [1975] pulls together Marx's ideas about culture and evolution). But for the most part systematic reading of the classics was deferred until later.

I think such a practice and study of practice provides a base for theory, and it is a particularly strong one in at least one important respect. Coming late to the "classics"

\footnotetext{
${ }^{4}$ Editors' note: FRELIMO, or Frente da Libertação de Moçambique, is the former governing party of Mozambique.
} 
from such a practice it is virtually impossible to relegate class struggle to a concluding paragraph or footnote as I'm afraid some in the spatial school have a tendency to do. Indeed this became a major issue at a recent meeting in Amsterdam of Marxist geographers 5 . If there is a danger that minute exegesis of Capital could become more for some geographers merely an intellectual challenge, like the rotating of matrices and calculation of eigen values was once for a slightly older group of "bright boys," it is not likely that those of us with a Third World practice (in the dual sense that either working there and/or having primarily an anti-imperialist/anti-fascist/anti-racist practice in Europe or North America) are likely to fall for it. Let me hasten to emphasize that I'm writing of tendencies, the tendency to drain Marxism of class struggle, reducing it merely to Kapitalslogik [the logic of capitalism]. I'm not meaning to imply criticism. I'm trying to build bridges with these notes, not start a polemic, which is another enervating tendency we should avoid!

How far can we push the apparent symmetry between the development of spatial and environmental theories? In my opinion a long way. The only limit is set by individual and class consciousness. If in most ways a set of "transformation functions" (Harvey, 1973) are possible for "mapping" environmental relations into spatial relations (but not vice versa??) and for "mapping" both environmental and spatial relations into more fundamental social relations (Anderson, 1977, 39; Peet, 1977, 23), it remains a fact that for the individual, as well as for class consciousness, environment (= place) has content that spatial relations can have but do not necessarily have. Environmental relations necessarily have content, meaning. This is the only limit to symmetrical treatment I can think of; however it is a large limit, and one I should return to later as it involves the most difficult question of the relation between Marxism and phenomenology.

The problem of consciousness notwithstanding, I believe it is probably worthwhile to try and think in terms of one unified Marxist geography. I agree with Peet that we have inherited the space/environment dichotomy from bourgeois geography - and a lot more baggage as well! On the other hand as tempting intellectually as is the "withering away" of geography altogether into a universal political economy with this or that specialized focus, I must resist. At the moment in Mozambique (and I'm sure elsewhere) Marxists are needed who can make maps, dig soil pits, and talk about erosion with peasants. We mustn't lose such skills, nor is it necessary.

5 "Zone Werkkongres: imperialisme en het ruimtelijk onderzoek van het perifeer kapitalisme" (Imperialism and the Spatial Organization of Peripheral Capitalism), Amsterdam, 11-13 May, 1977. 


\section{The "Crisis": Where and Whose?}

Peet gets us off on the wrong foot by seeming to juxtapose a "crisis in spatial relations" and an "environmental crisis." If a Marxist theory of environmental relations is called for at this conjuncture it is not because there is this kind of crisis or that kind of crisis, or even because there is cyclically recurring crisis, but because there is a continually growing contradiction between the level of production forces and the form of social labor. Preliminary and as of yet unsystematized observations from Asia (Cannon, 1977), Africa (O’Keefe, 1974; Wisner, 1977c), and Latin America (Johnson, 1977a) suggest that this fundamental contradiction produces a chronic disruption of peasant environmental relations quite distinct from the, not surprising, peaks of disruption which enter bourgeois consciousness from time to time as "food crisis," "drought crisis," or - more generally - "environmental crisis." Thus I believe a focus on "crisis" is neither necessary for providing Marxist environmental theory with a problematic, nor is it particularly useful, except as it focuses attention on crisis in the narrow sense of the periodic crisis of overproduction characteristic of capital development. This narrow sense of crisis is useful in explaining certain current contradictions between growing and declining regions and the decline in industrialurban environmental quality (Anderson, 1977).

The articulation of capitalist and non-capitalist (peasant) modes of production in the Third World is producing continually growing tensions between forces of production and social relations of production. In highland Kenya, the result has been erosion and proletarianization (Baird et al., 1977). In lowland Kenya, the result has been desertification and marginalization, where proletarianization is not possible (Hunt, 1975; Wisner, 1977c, 1977d, 1977e). In India, rapid development of productive forces - the so-called Green Revolution - in a social formation where peasant relations of production are frozen in articulated form with private capitalist, state capitalist, and residual feudal production relations, has meant correspondingly rapid subproletarianization of the peasantry. In Mexico, Johnson (1977b) describes a similar process:

The revolution and agrarian reform created a peasant sector - peasant communities - ill-equipped with the means for survival. In the meantime, the state provided ample institutional support for the development of large-holder capitalist agriculture. This support has intensified in the past twenty-five years. It is now clear that agrarian reform has been a key factor in enabling the large-scale development of capitalism in Mexican agriculture. ... This process has had a disintegrating effect on both peasant production and peasant communities. By destroying the relations of production underpinning the hacienda system, and at the same time by withholding institutional support that would ensure the survival of the peasant economy within an overall capitalist system, the Mexican agrarian reform has left the door 
open to the only other strong contender in the field: large-scale capitalist agriculture.

Such contradiction between peasant and capitalist modes of production and between forces and social relations of production give rise to "environmental problems" in South Asia (Cannon, 1977; Wisner, 1977f) and in Mexico (Johnson, 1977c) just as they give rise to them in highland and lowland Kenya. The details of distinct sub-processes differentiated by population density and by the tendency for displaced peasants to become proletarians or sub-proletarians (marginals), etc., need to be systematically worked through. However, classic descriptions exist for Indonesia (Geertz, 1966) and northeast Brazil (deCastro, 1969), and many examples are building up from African field work (Bondestam, 1975; Bugincourt, 1976; Copans, 1976; Habermeier, 1977; Kjekhus, 1976; Rey, 1975). Marxist environmental theory will arise from detailed study of such contradictions, not from a narrow focus on peaks in such processes which one terms "crisis".

\section{Approaches to Environmental Theory Building}

We are few, marginally or intermittently employed, and often dispersed; the task is large. Therefore I would encourage simultaneous work on as many fronts as possible. The following are three complimentary approaches:

\section{The Classic Texts}

I have already cited limited beginnings and some work in progress in this area. Although some studies of Marx's concept of nature exist (Mészáros, 1970; Schmidt, 1971), it would surely be useful for a group of geographers with an environmental practice to produce a commentary. Such an approach assumes that once one is clear about the Marxist concept of nature, then it is possible to move on without loss of clarity to the concept of environmental relations. A major problem with this approach is that, except for the early Marx and some Engels, most "statements" on nature must be extrapolated from some indirect references. This is certainly true of Lenin, Stalin, and Trotsky. One has better luck with Mao, but again, among "neoclassical" revolutionary authors Guevara and Amilcar Cabral have some important things to say, but need interpreting. The heroes and heroines of intellectual labor will find similar difficulties with secondary classical authors such as Bukharin, Luxemburg, Bebel, Kautsky, Gramsci, and Lukács - and possibly also diminishing returns since apart for the fundamental notion of the mutually-causing, dialectical relation between nature (as external physical reality, object of labor, and instrument of labor) and the human species (as socially laboring, self-conscious animal), any further detailed "statement" about environmental relations in classic texts is likely to be less important for our present-day theoretical needs than the general political economy, theories of 
imperialism, development, and consciousness contained in them. For that matter no classical author has all that much to say directly, explicitly about space! It is the application of theories of value, rent, surplus value, accumulation, circulation, and reproduction which has provided the framework for Marxist spatial theory building. The same basic framework is probably adequate for environmental dialectics, possibly with a different set of emphases (e.g. "reproduction" would be an important category in environmental theory - Wisner, 1977a).

\section{The Contemporary Marxist Development and Planning Literature}

A complementary basis for building up environmental theory may be the (predominantly Francophone) Marxist development planning literature utilizable either by working through some of the larger texts (e.g. Bettelheim, 1975) with an environmental perspective and/or by comparing the perspectives of authors who have begun to address environmental relations directly in shorter works (Amin, 1974; Sow, 1975). A major problem with this approach is that since these works are economic, development goals and planning frameworks are often taken as given - the very point where environmental dialectics would want to begin to pose questions. Also, there is a tendency for some of these authors to preserve uncritical residues of bourgeois environmental ideology in their assumptions, for instance, about the fertility of tropical soils. A useful non-economist discussion of basic needs is Blanc (1975).

\section{“Mode of Production” as Approach to Environmental Theory}

For Marx, the analysis of all human reality begins with production, and production "is a process of collective struggle between man and nature. One could conceive of it as a double relationship: between man and nature, and, at the same time, between man and man" (Dowidar, 1973-4, 37). In Capital (1970, Volume I, 177-8), Marx captures the primacy of production and the dialectical relation between people and nature as follows:

He [man] opposes himself to Nature as one of her own forces, setting in motion arms, legs, head and hands, and natural forces of his body in order to appropriate Nature's productions in a form adapted to his own wants. By thus acting on the external world and changing it, he at the same time changes his own nature.

One can ask the basic question how through collective struggle (i.e. social labor) people enter into this fundamental relationship with each other and with the external world - a relationship which both changes the world and themselves, a 
relationship that no representatives of the human species has ever been able to avoid. The answer to this question how is a description of mode of production.

It is easy to be mystified by the term "mode of production," although the German word Weise in the original term Produktionsweise has the simple and original meaning of manner, way to do something (Balibar, 1970, 209-10). Hence it is possible to define mode of production broadly as the manner in which a society produces, appropriates, and distributes its means of subsistence (Johnson, 1975).

If we enquire further into the relations to nature and relations among people which are organized into historically concrete labor processes, we find, on the one hand, forces of production (which Marx, 1970, Volume I, 178, defines as the "personal activity of man, i.e. work itself, the subject of that work, and its instruments") and, on the other hand, the social relations of production which organize labor, control access to instruments of work (also called "objects of labor" - e.g. the soil) and access to instruments of work (also called "instruments of labor" - e.g. hoes, ploughs, knowledge of soils), and control the appropriation and distribution of the result of human labor. Taken together, the objects and instruments of labor are sometimes referred to as the "means of production" which, together with human labor constitute the forces of production during any given historical period. Hindess and Hirst (1975, 910) summarize these definitions as follows:

A mode of production is an articulated combination of relations and forces of production structured by the dominance of the relations of production. The relations of production define a specific mode of appropriation of surplus-labor and the specific forms of social distribution of the means of production corresponding to that mode of appropriation of surplus-labor \{where "surplus-labor" can be defined as "production above that necessary to provide for the needs of the producing class" (Conference of Socialist Economists, 1976, 36)\}.

Hindess and Hirst $(1975,13)$ also note that each particular mode of production defines certain economic, ideological, or political conditions that are necessary for the existence of that structure of economic relations. These political, ideological, juridical conditions are (analytically) situated in the superstructure, which, in articulated combination with one or more modes of production ${ }^{6}$ (called "infrastructure" in contradistinction) constitutes a given social formation. Johnson (1977) refers to social formation as "the Marxian category of societal whole ... that is, the total structure incorporating all of society's economic, political, and ideological relations."

${ }^{6}$ Especially in the Third World one finds cases where the capitalist mode of production is combined with other modes such as "tribute paying" (Amin, 1977) or various peasant modes of production. This fact is vital to a theory of environmental relations and is returned to below. 
$[\ldots]$

Environmental relations - as conventionally defined in such disciplines as biogeography, agricultural geography, resource management, applied synecology, etc. as the totality of human relations with the biogeochemical "surround" or more narrowly defined as human "habitat" relations (Moss, 1969; Odum, 1971) - are clearly instances of production in the Marxist schema. The dialectical to-and-fro by which the human species creates nature, is created by nature, shapes tools, and is shaped by tools and by tool-making cannot be studied as a universal process, fixed for all time, but in its historically concrete forms and their development and change. Thus the bourgeois term "resource" can be translated as "object of labor." If we make this translation and then study the concrete historical forms in which these particular "objects of labor" are combined with labor and instruments of labor, we find, as Slater observes $(1977,68)$

... history reveals that the pace, pattern, form and social nature of resource utilization all vary with the relative levels of socio-economic development and, in particular, with changes in the relative sophistication of the instruments of labor ... these changes being inseparately linked to changes in the social organization of production and distribution.

Slater continues in a way that suggests a way of approaching at least one sort of environmental relation ("resource utilization") with Marxist analysis:

The whole complex of relationships among the existence of the objects of labor, the level of development of the instruments of labor, the nature of the social relations of production, the existence of a state of central social authority exerting control over the exploitation and utilization of objects of labor, the characteristics of a given culture and ideology, the size, density and demographic structure of the population, can only be effectively approached, analytically, in terms of an historically concrete method of investigation. That is the complex of relationships will fundamentally vary according to: (1) what kind of economic system we are studying, i.e., feudal, slave, developed capitalist, underdeveloped capitalist, post-capitalist, etc. and (2) the time and space context of the study.

This certainly constitutes a reasonable start. Other sorts of environmental relations can be dealt with in a similar way. For instance the relation "resource conservation" yields to analysis by the Marxian category of "reproduction." Every society needs to replenish its stock of means of production as well as its supply of human labor power. However, in Marxian analysis, reproduction is also taken to refer to the necessity of the social formation to recreate itself, to ensure its continuity through a complex of political and ideological institutions. In this light "resource 
conservation" can be seen also to serve an ideological function insofar as the ideology of conservation is often used to justify a particular class structure of access to certain objects of labor (e.g. banning peasant charcoal burners and hunters from forest reserves).

Development of a theory of environmental relations must also take into account that nature can also occur in the labor process as instrument of labor as well as object of labor. For instance Meillassoux (1972, 98-9) notes how "land" can be considered both object of labor (he uses the synonym "subject of labor") and instrument of labor:

At a low stage of development of the productive forces, when human energy is the only form of energy available and when tool-making requires comparatively little labor investment, the use of land as subject of labor amounts solely to the extraction of the necessities of life from it, as it is the case with hunting or collecting. At a higher stage of the development of productive forces, as in agriculture, man, with the expectation of a later return, invests his labor into the land, which becomes therefore an instrument of labor.

As a final example of the ability of Marxian analysis to deal with environmental relations conventionally of interest to geographers one might consider the relation "resource extinction" or "environmental degradation." Elsewhere (Wisner, 1977a, 1977d) I have described in detail how erosion, overgrazing, and deforestation in Kenya are the result of an articulation of the capitalist and peasant modes of production. First of all this articulation has produced severe landlessness in the highlands, resulting in overexploitation of the land. Landlessness has also demographic effects as streams of migrants seek land in lowlands. One chief articulation of the capitalist and peasant modes of production is the provision to the former of cheap labor power by the latter. This is achieved because male migrants working in the capitalist highlands leave behind a wife or wives whose domestic labor within the peasant mode of production helps to cover - indeed often fully covers - the cost or reproducing labor, allowing the capitalist to pay a wage which only covers the cost of the migrant's labor, not that of reproducing his family. Such an arrangement cuts deeply into the heart of the peasant mode of production, distorting it, but not destroying it. By siphoning off labor the forces of production are distorted. Also social relations of production are affected as mutual aid labor becomes more difficult. The combined effect of these and many other distortions is that the spatial and temporal flexibility of peasant environmental relations is reduced. In a highly variable environment (spatially and temporally) such as lowland Eastern Kenya, this means greater subsistence risk, more pressure for nonfarm income to support declining yields, hence over-exploitation of grazing and forest resources as peasants turn more and more to smaller livestock (goats and sheep) and charcoal-burning. Thus the environmental relation "degradation" is situated in the societal whole, the social formation. Tracing the links between underdeveloped capitalist production in Kenya and capitalist accumulation on a world scale, one makes 
the final step to the global system, which presumably even bourgeois geographers have desired to do since at least the time of von Humboldt's Kosmos.

One could continue to give examples of the way in which the historical materialist concept of mode of production, the conflict among modes of production, [...] and the uneven development of forces of production and social relations of production allows one to re-think environmental relations. For instance "resource assessment" immediately becomes not the absolute which seminars on the use of satellite imagery try to convince domestic (and alas foreign) students it is, but a human activity relative to a particular mode of production - e.g. the peasant mode to the Mezquital Valley of Mexico or the capitalist mode of production penetrating the same area through state irrigation development (Johnson, 1977c). What I have begun to sketch out for the relations "resource conservation," "environmental degradation," and "resource assessment" can be done for such relations as "environmental hazard," "carrying capacity," or "land use."

The whole analysis becomes theory when the set of different sorts of environmental relation is set in an historical panorama displaying the interrelations among such environmental relations during different periods in the development of class society from slave-owning to socialist. Parts of this panorama already exist in the work of such geographers as Suret-Canale (1973).

Of course, care must be taken to derive the set of environmental relations to be interrelated from the material reality of the humans concerned. This caveat has two aspects. First, clearly, some bourgeois categories of environmental relations would simply not be translated because they do not correspond to any material reality but only serve as ideological function within the capitalist economies of the industrial West. For instance "overpopulation" and "natural disaster" would not appear in Marxist theory either as such or in equivalent terms. Second, the subjective aspect of environmental relations must be included in the Marxist theory. Environmental relations not only have an objective existence as forms of production characteristic of a mode of production, they also have meaning for individuals and for groups. Johnson (1977a) has explored the role of environmental relations in the class consciousness of peasants in central México. As "resource knowledge" consciousness has an objective existence among the other forces of production whether or not it is recorded or embodied in material culture as technology. What I'm suggesting now is something related, but different. Whether we term it "topophilia" (Tuan, 1974) or something else, the fact remains that peasant resistance against seizure of land or disturbance of their relations with the environment is more than simply the defense of their economic interests. It is also a defense of "home," or of "place." Much more thinking is required on this subject, although Johnson has made an impressive start. Although there is controversy concerning the relationship between phenomenology and Marxism (Kruks, 1977; Lukács, 1948, 1971; Tran-Duc-Thao, 1971), I believe Marxist geographers should take up earlier urgings to explore phenomenology (Amaral and Wisner, 1970; 
Wisner, 1970) - although for different reasons than it was originally urged. If environmental relations have a significant role in the development of class consciousness and revolutionary consciousness, geography becomes an adjunct to revolutionary pedagogy and the pedagogy of the oppressed (Freire, 1971).

\section{Toward a Socialist Human Ecology}

So far, in outlining complementary approaches to Marxist environmental theory building, I have dwelt on scholarly activities: careful readings of Marxist classics for views of nature, selective borrowing from contemporary Marxist economic planners, detailed historical overview of the place of environmental relations in the evolution of modes of production. I would conclude these preliminary thoughts by returning to the theme of practice. Elsewhere I have argued that despite the fact that the term "human ecology" has been captured by an often fascist socio-biology, a socialist human ecology is not only possible but desirable, especially in Third World countries attempting a transition to socialism (Wisner, 1977a). The results of such a practice would find their place with the other sources of environmental theory. Especially as "ideas do not fall from the heavens", the parallel and overlapping development of a socialist human ecological practice and Marxist environmental theory are interdependent.

At the risk of repeating another similar catalog of research priorities $\left(\mathrm{O}^{\prime} \mathrm{Keefe}\right.$ and Wisner, 1977), some of the chief overlapping research foci of human ecology and political economy are listed below.

\section{Human Ecology}

(1) Environmental histories - utilizing oral history and contemporary inquiry, these studies would overview environmental variability and human response. Such studies would inquire into the role of women in shaping the landscape, the fate of nutritional systems and folk ecologies under the pressure of capital penetration. Impact studies of such ecological interventions as person-made lakes, large irrigation schemes, swamp drainage, sedentarization and other settlement schemas, exclusion and game park creation, etc. should all be conducted in the context of environmental history.

(2) Human adjustments - studying even the most radical changes in accessible means of production (e.g. pastoralists turning to fishing in Kenya) beginning with the assumption that these are rational survival strategies from the point of view of hard pressed groups. "Adjustments" would include turning to non-farm activities as discussed above. 
(3) System stability - asking a range of urgent, specific questions concerning the long-term consequences of the apparently decreasing diversity of crops, craft skills, etc. among peasant and pastoral peoples. For instance, of serious concern is the disappearance of many local legume varieties in lowland Kenya and the impoverishment of livestock gene-pools.

(4) The fate of folk ecologies in cooperative and other large-scale structures studying the applicability of ethnoscientific knowledge of land use and food system problems introduced by large-scale settlement, e.g. crop protection problems in Tanzania ujamaa villages (Sandberg, 1973; Wisner et al., 1978). Do folk ecologies disappear when people settle far from their homes? Can neighbors from different backgrounds share folk ecologies? Can ethnoscientific knowledge be integrated into education and literacy programs? Does the disappearance of folk ecology mean reduced adaptability to stress? Does folk ecology still have a useful function where socialist industrialization revolutionizes the productive forces in the rural areas of a country?

\section{Political Economy}

(1) Forms of extraction of surplus - focusing on the way in which changes in environmental relations influence the rate of extraction of surplus - especially from peasants involved in petty commodity production - and its realization as value through market relations. For instance, such a change in land use as satellite sugar production, in western Kenya, or the reemergence after a decade, in Tanzania, of cotton block farming should be studied from this point of view.

(2) Forms of struggle - asking whether class struggle and active resistance to unwanted impositions on environmental relations are the normal condition of the peasantry (Blaut et al., 1977). These studies would embrace the role of environmental relations (e.g. land use) in a continuum of forms of struggle which spans struggle and resistance embedded in cultural forms to wars of national liberation. Specific forms include sabotage of material infrastructure (e.g. terraces, irrigation works), the defense of land, the defense of production systems by nonadoption of innovations, flight from labor conscription, the withholding of produce and labor power, etc.

(3) Forms of accumulation, circulation and reproduction - focusing on the role of changing environmental relations in capital accumulation, its circulation and rural class formation. Study is also required of the crucial role played by women who assume, in the peasant household, a major responsibility in the sphere of reproduction. 
(4) Radical alternatives - following the creation of new social formations, such as after the independence of Mozambique, which challenge one to consider the implications of rapid transformation of peasant and plantation land use into transitional socialist forms such as the communal village (aldeia communal) and state farm (Wisner, 1977g). For instance, do radical new relations between people, party, and state release energies capable of resolving centuries-old environmental problems such as erosion in the Cape Verde Islands (Davidson, 1977)?

\section{References}

Akatiff, C. 1974. Geography and the Working Class: A Marxian Survey. Saklan Institute of Anthropology, Professional Paper No. 1, P.O. Box 4282, CA 94704, May Day [USA].

Amaral, D. and Ben Wisner. 1970. Participant observation, phenomenology, and the rules for judging sciences. Antipode 2(1), 42-51.

Amin, S. 1977. Unequal Development: An Essay on the Social Formations of Peripheral Capitalism. Sussex: Harvester.

Amin, S. 1973. Les problémes de l'environnement en Afrique [Environmental problems in Africa]. Éspaces et Sociétés, 10-11, 7-14.

Anderson, J. 1977. Geography, political economy and the state. Journal of St. Andrews Geographers, Special Publication No. 2.

Baird, A., P. O'Keefe and B. Wisner. 1977. Kenyan underdevelopment: A case study of proletarianization. In, P.O'Keefe \& Ben Wisner (eds.), Landuse and Development. London: International African Institute, pp. 216-28.

Baird, A., P. O'Keefe, K. Westgate and B. Wisner. 1975. Toward an explanation and reduction of disaster proneness. Paper presented at Bradford University, Disaster Research Unit, Occasional Paper No. 11.

Balibar, E. 1970. Basic concepts of historical materialism. In, L. Althusser \& E. Balibar (eds.), Reading Capital. London: New Left Books, pp. 199-308.

Battelheim, C. 1975. A Planificação Socialista da Economia [Socialist Planning of the Economy]. Lisboa: Edicões 70.

Blanc, J. 1975. Nutrition et Developpement. Université de Grenoble and Maspéro: Paris.

Blaut, J. 1977. Some principles of ethnography. Unpublished paper. Chicago. 
Blaut, J. 1975. Imperialism, the Marxist theory and its evolution. Antipode 7(1), 1-19.

Blaut, J. 1973. The theory of development. Antipode 5(2), 22-6.

Blaut, J. 1970. Geographic models of imperialism. Antipode 2(1), 65-85.

Blaut, J., K. Johnson, P. O'Keefe and B. Wisner. 1977. Theses on peasantry. Antipode $9(2), 125-7$.

Bondestam, L. 1975. Population et capitalisme dans la vallée de l'Aouache (Éthiopie) [Population and capitalism in the Awash Valley, Ethiopia]. In, S. Amin (ed.), L'Agriculture Africaine et le Capitalisme [African Agriculture and Capitalism]. Editions Anthropos/IDEP: Paris.

Buchanan, K. 1973. The white north and the population explosion. Antipode 5(3), 715.

Bugnicourt, J. 1976. Paysages Déchirés, Environnements Menacés dans le Delta et la Vallée du Senegal [Ruined Countryside, Threatened Environments in the Delta and Valley of Senegal]. Environnement Africain Études et Récherches No. 10. Dakar: ENDA/IAI.

Cannon, T. 1977. "Natural" disasters and the third world. Journal of St. Andrews Geographers, Special Publication No. 2.

Conference of Socialist Economists.1976. On the Political Economy of Women. London: Stage 1.

Copans, J. (ed.). 1975. Famines et Sécheresses en Afrique [Famines and droughts in Africa], 2 volumes. Paris: Maspero.

Datoo, B. 1977. Peasant agricultural production in East Africa: The nature and consequences of dependence. Antipode 9(1), 70-8.

Davidson, B. 1977. Mass mobilization for national reconstruction in the Cape Verde Islands. Economic Geography 53(4), 393-6.

DeCastro, J. 1969. Death in the Northeast. New York: Random House/Vintage.

Dowidar, M. 1973-4. Les concepts: Du mode de production à la région. Éspaces et Societés 10-11, 37-44.

Enzensberger, H.M. 1974. A critique of political ecology. New Left Review 84, 3-31.

Freire, P. 1971. Pedagogy of the Oppressed. London: Penguin. 
Galois, B. 1976. Ideology and the idea of nature: The case of Peter Kropotkin. Antipode 8(3), 1-16.

Geertz, C. 1966. Agricultural Involution. Berkeley: University of California Press.

Habermeier, K. 1977. Bauerliche Gemeinschaften, Kapitalistische Exportwirtschaft und Wanderarbeit in Westafrika [Peasant Societies, Capitalist Export Economy and Migrant Labour in West Africa]. Karlsruhe: Verlag M. Wahl.

Harvey, D. 1974. Environment, resources and people. Economic Geography 50(3), 256-77.

Harvey, D. 1973. Social Justice and the City. London: Arnold.

Hindess, B. and P. Hirst. 1975. Precapitalist Modes of Production. London: Routledge and Kegan Paul.

Hunt, D. 1975. Poverty and Agricultural Development Policy in a Semi-Arid Area of Eastern Kenya. University of Nairobi, Institute for Development Studies, Occasional Papers No. 11.

Hunt, E. and Sherman H. 1972. Pollution in radical perspective. Business and Society Review 3, 48-53.

Johnson, K. 1977a. Do as the land bids: A study of Otomi resource-use on the eve of irrigation. Unpublished Ph.D. Thesis, Clark University: Worcester, MA.

Johnson, K. 1977b. Agricultural collectivization and village level studies in Mexico. Paper for symposium on Village Level Studies, Clark University: Worcester, MA.

Johnson, K. 1977c. Disintegration of a traditional resource-use complex: The Otomí of the Mezquital Valley, Hidalgo, México. Economic Geography 53(4), 364-7.

Johnson, K. 1975. Marx on cultural evolution: A review. Antipode 7(2), 1-8.

Kassami, A., A. Nuwagaba and B. Wisner. 1975. Mbambara: The long road to Ujamaa. In, L. Cliffe et al. (eds.), Rural Cooperation in Tanzania. Dar es Salaam: Tanzania Publishing House, pp. 370-91.

Kjekhus, H. 1976. Ecological Control and Economic Development in East African History. London: Heinemann.

Kruks, S. 1977. The political thought of Merleau-Ponty. Unpublished Ph.D. Thesis, University of London. 
Lukács, G. 1971/1923. History and Class Consciousness. Trans. R. Livingstone. London: Merlin Press.

Lukács, G. 1948. Existentialisme ou Marxisme? [Existentialism or Marxism] Paris: Nagel.

Marx, K. 1970/1867. Capital, Volume 1. London: Lawrence and Wishart.

Meillassoux, C. 1972. From reproduction to production: A Marxist approach to economic anthropology. Economy and Society 1(1), 93-105.

Mészáros, I. 1970. Marx’s Theory of Alienation. London: Merlin Press.

Moss, R. P. 1969. The appraisal of land resources in tropical Africa: A critique of some concepts. Pacific Viewpoint 10, 18-27.

Odum, E. 1971. Fundamentals of Ecology. New York: W. Saunders.

O'Keefe, P. 1974. Gakarara: The development of underdevelopment. Unpublished Ph.D. Thesis, University of London.

O'Keefe, P. and B. Wisner (eds.). 1977. Landuse and Development. London: International African Institute.

O'Keefe, P. and B. Wisner. 1975. African drought: The state of the game. In, P. Richards (ed.), African Environment: Problems and Perspectives. London: International African Institute, pp. 31-9.

Olwig, K. 1976. The ideology of conservation: The case of the Caribbean. Unpublished Ph.D. Thesis, University of Wisconsin.

Peet, R. (ed.). 1977. Radical Geography. Maaroufa Press: Chicago.

Rey, P. 1975. Les formes de la décomposition des sociétés précapitalistes au Nord Togo et le mécanisme des migrations vers les zones de capitalisme agraire [Form and breakdown of precapitalist societies in North Togo and the mechanism of migration towards the zones of agrarian capitalism]. In, S. Amin (ed.), L'Agriculture Africaine et le Capitalisme [African Agriculture and Capitalism]. Paris: Éditions anthropos/IDEP, pp. 233-56.

Ridgeway, J. 1971. The Politics of Ecology. New York: Dutton.

Rieser, R. 1973. The territorial illusion and the behavioral sink: Critical notes on behavioral geography. Antipode 5(3), 52-7. 
Sandberg, A. 1973. Ujamaa and Control of the Environment. Mimeo. University of Dar es Salaam, Bureau of Resource Assessment and Land Use Planning.

Santos, M. 1975. Space and domination: A Marxist approach. International Social Science Journal 27(2), 346-2.

Schmidt, A. 1971. Marx's Idea of Nature. London: New Left Books.

Schmidt-Renner, G. 1974. Sozialistischer Umweltschutz unter volkswirtschaftlichen Gesichtspunkten [Socialist environmental protection under economic viewpoints]. Petermanns Geographische Mitteilungen 118(1), 9-18.

Schmidt-Renner, G. 1973a. Zur territorialen Existenz und Bewegungsform der sozialistischen gesellschaftlichen Reproduktion [On territorial existence and forms of movement of socialist social reproduction]. Petermanns Geographische Mitteilungen 117(4), [259-67].

Schmidt-Renner, G. 1973b. Über territoriale Verhaltensweisen bei der Reproduktion von Arbeitskraft und Bevölkerung in der DDR [Of territorial modes of behaviour in the reproduction of labour and population in the GDR]. Petermanns Geographische Mitteilungen 117(3), [192-205].

Schmidt-Renner, G. 1972. Zur sozialistischen Ökologie des Menschen in Siedlungen [On socialist Ecology of People in Settlements]. Petermanns Geographische Mitteilungen 116(3), [161-175].

Schmidt-Renner, G. 1966. Elementäre Theorie der Ökonomischen Geographie [Elementary Theory of Economic Geography]. Gotha: VEB Herman Haack.

Slater, D. 1977. Resources and class structure: Notes on an alternative Marxist perspective. Antipode 9(1), 68.

Sow, S. 1975. Systéme et environnement [System and environment]. In, S. Amin, M. Franco and S. Sow (eds.), La Planification du Sous-Développement [Planned Underdevelopment]. Paris: Éditions-Anthropos/IDEP, [pages unknown].

Suret-Canale, J. 1973. Afrique Noir: Géographie, Civilisations, Histoire [Black Africa: Geography, Civilisation, History]. $3^{\text {rd }}$ ed. Paris: Sociales.

Tran-Duc-Thao. 1971. Phénomenologie et Matérialisme Dialectique [Phenomenology and Dialectical Materialism]. Paris: Gordon Breach.

Tschannerl, G. 1975. Rural Water Supply in Tanzania. African Environment 1(3), 5176.

Tuan, Y. 1974. Topophilia. New York: Prentice Hall. 
Weinberg, B. 1971. Beyond Repair: The Ecology of Capitalism. Beacon: Boston.

Wisner, B. 1977a. Viva os continuadores: Child welfare as human ecological tool in national planning. Journal of St. Andrews Geographers, Special Publication No. 2.

Wisner, B. 1977b. The human ecology of drought in eastern Kenya. Unpublished Ph.D. Thesis, Clark University, Worcester MA.

Wisner, B. 1977c. Constriction of a livelihood system: The peasants of Tharaka Division, Meru District, Kenya. Economic Geography 53(4), 353-7.

Wisner, B. 1977d. Studies of articulation and reproduction in Kenya. Working Party on Underdevelopment. Paper presented at the Conference on Black Africa, Development Center, Faculty of Sociology, University of Bielefeld, Bielefeld, West Germany, 28 April-1 May.

Wisner, B. 1977e. Man-made famine in Eastern Kenya. In, P. O'Keefe \& B. Wisner (eds.), Landuse and Development. London: International African Institute, pp. 216-28.

Wisner, B. 1977f. Global systems and local disasters: The untapped powers of people's science. Disasters 1(1), 47-57.

Wisner, B. 1977g. Agriculture in Mozambique. Science for People (London) 34 [pages unknown].

Wisner, B. 1976. Health and the geography of wholeness. In, G. Knight and J. Newman (eds.), Contemporary Africa. New York: Prentice-Hall, pp. 81-100.

Wisner, B. 1975a. Famine relief and people's war. Review of African Political Economy 3, 77-83.

Wisner, B. 1970. Protogeography. Paper presented to the symposium New Departures in Theoretical Cultural Geography, $66^{\text {th }}$ Annual Meeting of the Association of American Geographers, San Francisco, August.

Wisner, B. and P. Mbithi. 1973. Drought and famine in Kenya: Magnitude and attempted Solutions. Journal of East African Research and Development 3(2), $113-43$. 